\title{
Modified Bone Cement: A Reprieve for Horizontal Bone Defects
}

\author{
Lakshmi Puzhankara
}

\begin{abstract}
Introduction: Periodontitis results in defects of the bone, of which the horizontal defects are the most common. Treatment options for horizontal defects are minimal with unpredictable results.
\end{abstract}

Background: Polymethyl methacrylate (PMMA) bone cement has been effectively used in orthopedic surgeries. The material has excellent interface integrity with bone and hence would develop an efficient micromechanical bond to both bone and tooth. This material can be used to reconstruct the lost alveolar bone, especially in areas with horizontal bone defects where regeneration is difficult to achieve.

Results: The PMMA bone cement has certain properties that make it a not very apt replacement of the dynamic alveolar bone. However, modification of the cement through addition and replacement of appropriate materials would make it an effectual foundation for the teeth deprived of their alveolar bone.

Conclusion: Bone cement, with appropriate modifications, might prove a novel substitute for the lost alveolar bone structure.

Clinical significance: Horizontal bone defects that form the majority of periodontal bone defects require a definitive treatment modality to allow for retention of the affected teeth. Modified bone cement could prove to be the much required miracle agent in the treatment of horizontal bone defects.

Keywords: Bone cement, Horizontal bone defects, Polymethyl methacrylate.

How to cite this article: Puzhankara L. Modified Bone Cement: A Reprieve for Horizontal Bone Defects. World J Dent 2017; 8(5):425-427.

Source of support: Nil

Conflict of interest: None

\section{BACKGROUND}

Periodontitis, an infectious and inflammatory disease of the periodontium, is one of the major causes of tooth mortality, especially in the adult population. The inflammatory process usually begins in the soft tissue and then spreads to involve the underlying alveolar bone. Involvement of the bone results in gradual breakdown of the bone

Department of Periodontology, School of Dentistry, Amrita University, Amrita Vishwa Vidyapeetham, Kochi, Kerala, India

Corresponding Author: Lakshmi Puzhankara, Department of Periodontology, School of Dentistry, Amrita University Amrita Vishwa Vidyapeetham, Kochi, Kerala, India, e-mail: lakshmi.p.menon83@gmail.com architecture; eventually the bone support collapses and it results in tooth loss. ${ }^{1}$

On reflection, it can be said that the ultimate cause of tooth loss is the loss of bone. ${ }^{1}$ The pattern in which bone loss occurs is varied. Alignments of teeth, position of root within the alveolar process, and proximity with another tooth surface are a few of the factors that determine the pattern of bone loss. ${ }^{2}$ The bone destruction patterns may be horizontal, vertical, ledge-like, reversed architecture, or furcation involvement. ${ }^{3}$

Of all the bone destruction patterns that are present, horizontal bone loss is the most common. ${ }^{3}$ Therefore, treatment modalities that help in repair and rebuilding of horizontal defect are vital in total periodontal reconstruction. Attempts have been made to correct the horizontal defects using bone graft materials, biological mediators, and guided tissue regeneration. ${ }^{4,5}$ However, the supracrestal bone regeneration has remained a mirage ${ }^{6}$ with very little recorded success. ${ }^{4,5}$

The use of PMMA bone cement in orthopedic surgery is a time-proven and effective treatment modality for vertebral body reconstruction, total joint arthroplasty, repair of open fractures, etc. ${ }^{7,8}$ The interface integrity of the material can be considered a valuable asset in its use as a bone cement. ${ }^{8}$ The same property can be considered pivotal in its use as a material to reconstruct the horizontal ridge defect. It can be theorized that the cement can act as a foundation for the teeth lacking in support from the natural alveolar process, thereby stabilizing the teeth. The cement may be used even in dentulous areas as its natural properties would allow it to establish a micromechanical bond with the tooth. This material, with certain modifications, may very well prove to be a savior for a horde of teeth.

\section{REVIEW RESULTS}

German chemist Dr Otto Rohm patented the PMMA product Plexiglass in 1933, which was used for nonmedicinal purposes. ${ }^{9}$ The discovery made by Kulzer that the dough formed by mixing PMMA powder and a liquid monomer hardens under appropriate conditions and with the addition of the required materials ${ }^{10}$ was made use of in 1938 for the first time to close cranial defects in monkeys. Later, PMMA was used to close cranial defects in humans in the form of heat-stable polymer Paladon $65 .{ }^{10}$ 
Degussa and Kulzer introduced the era of modern PMMA bone cements. ${ }^{10}$ This technology was put into use by dental surgeons for the preparation of dental appliances and fixatives. Charnley ${ }^{11}$ used this "dental acrylic" in 1958 for total hip arthroplasty as it had the ability of micromechanical bonding to bony structures. Nevertheless, the initial clinical results were poor due to mechanical and biological reasons. ${ }^{10}$ In order to overcome the shortcomings of the "dental acrylic" as an orthopedic cement, a newer material called "bone cement" was developed by Charnley ${ }^{12}$ which had more compliant biological properties. ${ }^{13}$ However, this material also proved to have many shortcomings. Several modifications of this material have been developed using additives to improve the properties of the cement. ${ }^{14}$

There is no evidence in the literature that points toward the use of PMMA bone cement, in a modified form, in the treatment of horizontal bone defects. When deliberated over as a possible synthetic part of the periodontium, PMMA bone cement can be considered as a material with certain surmountable shortcomings. The development of modified PMMA cement for horizontal defects will prove to be a milestone in the treatment of horizontal bone defects.

\section{DISCUSSION}

Mechanical weakness of the cement due to the presence of additives like barium sulfate and zirconium oxide is a drawback of using the cement as it may cause the entire foundation to loosen. ${ }^{15}$ However, addition of steel fibers, glass fibers, carbon fibers, and titanium fibers improves the mechanical strength, ${ }^{16-18}$ while PMMA matrix interspersed with rubber particles can increase the fracture toughness of the material. ${ }^{19}$ Embedded stainless steel coil increases the compressive strength of the material, ${ }^{20}$ but the steel coils may interfere with its usefulness as a reconstructive material in dentulous sites.

Interface integrity, which refers to the strength of bonding of the cement to the bone and the degree of cement penetration, is a critical element in the success of alveolar reconstruction. The addition of glutaraldehyde, an amphiphilic bonder, may lead to significant improvements in the surface integrity and longevity of the cement. ${ }^{21}$

Osteoconduction, a property that allows the migration of osteogenic cells; osteoinduction, the capability of a material to cause the cells adjacent to the implanted site to become osteogenic; and osteogenesis, the ability of the material itself to generate new bone allow for development of a natural bone structure to replace lost bone. This regeneration of new bone would require the addition of bioactive materials and biological factors into the cement. The addition of more than $60 \%$ by weight of bioactive ceramic powder into PMMA would make the cement osteoconductive. ${ }^{22}$ Bone morphogenetic proteins and transforming growth factor or platelet-rich fibrin, which is a storehouse of growth factors, when added into the cement, would increase its biocompatibility and might also make it osteogenic. ${ }^{23}$

The exothermic reaction that occurs during setting of PMMA is hazardous for the survival of the vital tissues adjacent to the implanted material; 1-dodecyl mercaptan ${ }^{24}$ and $\mathrm{N}$-acetyl cysteine $\mathrm{e}^{25}$ are additives that can reduce the polymerization temperature.

Apart from being an exothermic reaction, the polymerization of PMMA utilizes a redox system that produces amine- and benzoate-free radicals. These free radicals can induce local inflammation and modify the activity of macrophages. ${ }^{26}$

Vitamin E, a free radical scavenger, can be added to PMMA to improve its properties. ${ }^{27}$ Addition of $10 \%$ vitamin E to PMMA reduces peak polymerization temperature without affecting the mechanical strength significantly. It also improves cement cytocompatibility. ${ }^{8}$

Barium sulfate and zirconium oxide, which are used to render the PMMA radiopaque, reduce its mechanical strength. ${ }^{28}$ But addition of radiopaque ceramic nanoparticles like nanoMgO and nanoBaSO ${ }_{4}$ does not have a significant effect on mechanical strength of the material. They also improve osteoblast adhesion; nanoMgO has also been shown to minimize tissue necrosis. ${ }^{29}$

A site with periodontal disease is a storehouse of microorganisms. Debridement of the site during open flap debridement removes a bulk of the microbiota. However, a minute quantity of the organisms might persist, which in turn can result in the collapse of the implanted material. The addition of certain antibiotics into PMMA would serve to protect the material from microbial attack. Tobramycin and gentamicin can be used as antibiotic additives. ${ }^{30} 2 \mathrm{~g}$ per $60 \mathrm{~g}$ or $2 \mathrm{~g}$ per $40 \mathrm{~g}$ of Gentamicin has been shown to reduce post-operative infection rates ${ }^{31}$ without a significant alteration in the compressive or diametral tensile strength. ${ }^{8}$ Chitosan nanoparticles have been shown to have significant antibacterial activity against Staphylococcus aureus and Staphylococcus epidermidis in in vitro studies. ${ }^{32}$ The $1 \%$ silver nanoparticles have antibacterial activities against Acinetobacter baumannii, Pseudomonas aeruginosa, Proteus mirabilis, and S. aureus. However, there is a reduction in mechanical strength of the cement with the addition of silver nanoparticles. ${ }^{33}$

\section{CONCLUSION}

Development of a bone cement material that includes all the desired properties while excluding all the undesired properties is a task that requires to be addressed. Further research has to be conducted to ensure the viability of the material for clinical use. 


\section{CLINICAL SIGNIFICANCE}

Horizontal defects form the majority of periodontal bone defects. Reconstruction of these horizontal bone defects has been a much sought after treatment outcome, yet it remains an elusive target for periodontists. Modified bone cement could prove to be the much required miracle agent in the treatment of horizontal bone defects.

\section{REFERENCES}

1. Carranza, FA.; Takei, HH. Bone loss and patterns of bone destruction. In: Newman MG, Takei HH, Klokkevold PR, Carranza FA, editors. Carranza's periodontology. 10th ed. Noida: Saunders, Reed Elsevier India Private Limited; 2006. p. 452.

2. Carranza, FA.; Takei, HH. Bone loss and patterns of bone destruction. In: Newman MG, Takei HH, Klokkevold PR, Carranza FA, editors. Carranza's periodontology. 10th ed. Noida: Saunders, Reed Elsevier India Private Limited; 2006. p. 458.

3. Carranza, FA.; Takei, HH. Bone loss and patterns of bone destruction. In: Newman MG, Takei HH, Klokkevold PR, Carranza FA, editors. Carranza's periodontology. 10th ed. Noida: Saunders, Reed Elsevier India Private Limited; 2006. p. $459-462$.

4. Yilmaz S, Kuru B, Altuna-Kirac E. Enamel matrix proteins in the treatment of periodontal sites with horizontal type of bone loss. J Clin Periodontol 2003 Mar;30(3):197-206.

5. Warrer K, Karring T. Guided tissue regeneration combined with osseous grafting in suprabony periodontal lesions. J Clin Periodontol 1992 Jul;19(6):373-380.

6. Kotschy P, Laky M. Reconstruction f supracrestal alveolar bone lost as a result of severe chronic periodontitis: five-year outcome: case report. Int J Periodontics Restorative Dent 2006 Oct;26(5):425-431.

7. Reddy JPK, Murthy P, Nazeer BS, Manohar PV, Anil Kumar SV. Vertebral body reconstruction using antibiotic impregnated bone cement (PMMA) in osteomyelitis of lumbar spine: case reports. Int J Biomed Adv Res 2015 Feb;6(02):191-195.

8. Arora M, Chan EKS, Gupta S, Diwan AD. Polymethylmethacrylate bone cements and additives: a review of the literature. World J Orthop 2013 Apr;4(2):67-74.

9. Nottrott M. Acrylic bone cements: influence of time and environment on physical properties. Acta Orthop Suppl 2010 Jun;81(341):1-27.

10. Kuhn, KD. Properties of bone cement-what is bone cement? Chapter 3.1. In: Breusch SJ, Malchau H, editors. The well-cemented total hip arthroplasty: theory and practice. Germany: Springer; 2005. p. 51-59.

11. Charnley J. Anchorage of the femoral head prosthesis to the shaft of the femur. J Bone Joint Surg Br 1960 Feb;42-B:28-30.

12. Charnley J. Acrylic cement in orthopaedic surgery. Br J Surg 1970 Nov;57(11):874.

13. Waugh, W. John Charnley-the man and the hip. 1st ed. Germany: Springer; 1990. p. 1-268.

14. Lewis G. Alternative acrylic bone cement formulations for cemented arthroplasties: present status, key issues, and future prospects. J Biomed Mater Res B Appl Biomater 2008 Feb;84(2):301-319.

15. Sylvain GM, Kassab S, Coutts R, Santore R. Early failure of a roughened surface, precoated femoral component in total hip arthroplasty. J Arthroplasty 2001 Feb;16(2):141-148.
16. Bowman AJ, Manley TR. The elimination of breakages in upper dentures by reinforcement with carbon fibre. Br Dent J 1984 Feb;156(3):87-89.

17. Khaled SM, Charpentier PA, Rizkalla AS. Physical and mechanical properties of PMMA bone cement reinforced with nano-sized titania fibers. J Biomater Appl 2011 Feb;25(6): 515-537.

18. Stipho HD. Effect of glass fiber reinforcement on some mechanical properties of autopolymerizing polymethyl methacrylate. J Prosthet Dent 1998 May;79(5):580-584.

19. Puckett AD, Roberts B, Bu L, Mays JW. Improved orthopaedic bone cement formulations based on rubber toughening. Crit Rev Biomed Eng 2000;28(3-4):457-461.

20. Frigstad JR, Park JB. Reinforcement of PMMA bone cement with a continuous wire coil-a 3D finite element study. Biomed Mater Eng 1996 Feb;6(6):429-439.

21. Marx R, Faramarzi R, Jungwirth F, Kleffner BV, Mumme T, Weber M, Wirtz DC. Silicate coating of cemented titanium based shafts in hip prosthetics reduces high aseptic loosening. Z Orthop Unfall 2009 Mar-Apr;147(2):175-182.

22. Tsukeoka T, Suzuki M, Ohtsuki C, Sugino A, Tsuneizumi Y, Miyagi J, Kuramoto K, Moriya H. Mechanical and histological evaluation of a PMMA-based bone cement modified with gamma-methacryloxypropyltrimethoxysilane and calcium acetate. Biomaterials 2006 Jul;27(21):3897-3903.

23. Hallman M, Thor A. Bone substitutes and growth factors as an alternative/complement to autogenous bone for grafting in implant dentistry. Periodontol 20002008 Jun;47(1):172-192.

24. Endogan T, Kiziltay A, Hasirci V, Hasirci N. Modification of acrylic bone cements with oxygen plasma and additives. JBT 2012 Sep;2(3):236-243.

25. Cheng Y, Yang HC, Cho JH, Lee SH, Lim BS. The effect of $\mathrm{N}$-acetylcysteine addition on the polymerization behavior of PMMA bone cement. Macromol Res 2012 Sep;20(9):928-938.

26. Lewis G. Properties of acrylic bone cement: state of the art review. J Biomed Mater Res 1997 Summer;38(2):155-182.

27. Méndez JA, Aguilar MR, Abraham GA, Vázquez B, Dalby M, Di Silvio L, San Román J. New acrylic bone cements conjugated to vitamin E: curing parameters, properties, and biocompatibility. J Biomed Mater Res 2002 Nov;62(2):299-307.

28. Cisneros-Pineda OG, Cauich-Rodríguez JV, Cervantes-Uc JM, Vázquez B, Román JS. Combined influence of barium sulfate content and co-monomer concentration on properties of PMMA bone cements for vertebroplasty. J Biomater Sci Polym Ed 2011 Jan;22(12):1563-1580.

29. Ricker A, Liu-Snyder P, Webster TJ. The influence of nano $\mathrm{MgO}$ and $\mathrm{BaSO}_{4}$ particle size additives on properties of PMMA bone cement. Int J Nanomedicine 2008 Mar;3(1): 125-132.

30. Jiranek WA, Hanssen AD, Greenwald AS. Antibiotic loaded bone cement for infection prophylaxis in total joint replacement. J Bone Joint Surg Am 2006 Nov;88(11):2487-2500.

31. Marks KE, Nelson CL, Lautenschlager EP. Antibioticimpregnated acrylic bone cement. J Bone Joint Surg Am 1976 Apr;58(3):358-364.

32. Shi Z, Neoh KG, Kang ET, Wang WW. Antibacterial and mechanical properties of bone cement impregnated with chitosan nanoparticles. Biomaterials 2006 May;27(11): 2440-2449.

33. Buchholz HW, Elson RA, Heinert K. Antibiotic-loaded acrylic cement: current concepts. Clin Orthop Relat Res 1984 Nov;(190):96-108. 